\title{
ANALYSIS OF TRACHEID MORPHOLOGICAL CHARACTERISTICS, ANNUAL RINGS WIDTH AND LATEWOOD RATE OF CUPRESSUS FUNEBRIS IN RELATION TO CLIMATE FACTORS
}

\author{
Jianhua Lyu, Weihui Huang, Ming Chen, Xianwei Li, Shilin Zhong \\ Siyuan Chen, Jiulong Xie \\ Sichuan Agricultural University \\ China
}

(Received October 20I9)

\begin{abstract}
Based on the principle of tree chronology, this paper measures tracheid morphological characteristics, ring width, and latewood rate of harvested wood from Cupressus funebris plantation in Deyang, Sichuan Province. Using meteorological data of average temperature, precipitation, relative humidity, sunshine percentage, and average ground temperature from 1983 to 2015, correlation analyses were conducted. The results of the analysis showed that the correlation between tracheid morphological characteristics, ring width, and latewood rate was not consistent with a single climatic factor. Moreover, the correlation between tracheid morphological characteristics and climatic factors, and the correlation between ring width, latewood rate, and climatic factors were significantly different. Temperature was the main limiting factor for ring width and latewood rate. In addition, relative humidity was positively correlated with ring width and negatively correlated with most indicators of tracheid morphological characteristics. Fewer indicators were affected by sunshine percentage. Meanwhile, precipitation was not significantly correlated with ring width and latewood rate. In conclusion, the correlation between various indicators and climate factors was from high to low in order of temperature, relative humidity, sunshine percentage, and precipitation.
\end{abstract}

KEYWORDS: Cupressus funebris, tracheid morphology, climatic factors, correlation.

\section{INTRODUCTION}

Temperature, sunshine, precipitation, and humidity are the main climatic factors, which play an important role in the growth of trees. The morphological characteristics of wood tracheids have obvious variability and difference among tree species and in the same tree species (Antonova 
and Stasova 1997). Many research studies have focused on correlation analyses between tracheid morphological characteristics, annual rings of wood, and climatic factors. Tracheid length, diameter, and wall thickness had different responses to climate change (Zhao and Guo 2009a, Nabais et al. 2014, Begum et al. 2018). Some of these studies have found that a number of indicators, such as tracheid length, cell-wall percentage, latewood tracheid size, and wall thickness are positively correlated with temperature of a particular time period (Song and Huang 1995, Guo 1999, Yasue et al. 2000, Olano et al. 2012). Conversely, some studies have found that the number of tracheids and tracheid wall thickness were negatively correlated with temperature of a particular time period (Olano et al. 2012). In addition, some studies have found that the effect of temperature on tracheid length has a lagging effect (Zhao and Guo 2009b, Vichrová et al. 2013). Similarly, other researchers have found that some indicators, such as tracheid length, tracheid diameter, tracheid wall thickness, annual ring width, annual ring density and so on were associated with precipitation, temperature and other climatic factors (Song and Huang 1995, Guo 1999, Jonsson et al. 2002, Masiokas and Villalba 2004, Hacura et al. 2015, Kalbarczyk and Ziemiańska 2016, Ziemiańska and Kalbarczyk 2018). Moreover, some studies were carried out on the impact of extreme climate conditions on tracheid morphological characteristics, which have showed the decrease of lumen width, cell wall thickness and the number of tracheid in the tree rings at heavily damaged site, and significant difference was shown between sites with different damage level (Samusevich et al. 2017). Research literature regarding Cupressus funebris mainly focuses on forest resource management, variation of wood properties, chemical constituent of essential oils, and physical and mechanical properties of wood products (Fan et al. 2014, Lyu et al. 2018, Chen et al. 2018, Chen and Lyu 2018, Chen et al. 2019). Moreover, studies on the correlation between tracheid morphological characteristics of $C$. funebris and climate factors are very rare.

This study aims to analyze the adaptability of $C$. funebris tree species to climate change using dendrochronology, and to investigate the relationship between tracheid morphology, ring width, latewood rate of $C$. funebris and main climate factors, which could provide a theoretical basis for high quality cultivation of $C$. funebris wood and guide the cultivation practice of $C$. funebris plantations.

\section{MATERIAL AND METHODS}

\section{Materials}

The experimental wood was collected from a C. funebris plantation forest located in Jingyang District, Deyang City, Sichuan Province, China. Twenty C. funebris trees were randomly selected from $20 \times 20 \mathrm{~m}$ sample plots without any treatment. Three cores were drilled per tree with a $5.15 \mathrm{~mm}$ diameter borer. In order to avoid tree ring squeezing from slope gradient, the trees were bored at breast height ( $1.3 \mathrm{~m}$ from the ground) in line with the contour of the hillside or in the vertical direction with the slope (Jiang et al. 2018). The north-south direction of each sample was marked. The samples were put into an incubator and transported to the laboratory.

\section{Methods}

\section{Determination of ring width and latewood rate}

Core samples were processed according to the conventional dendrochronology science method (Fritts 1976). Samples were air-dried before a treatment. Core samples were fixed in glass troughs $400 \mathrm{~mm}$ long, $5 \mathrm{~mm}$ wide, and $3 \mathrm{~mm}$ deep, which were made of glass sheets. In this way, core samples were not damaged during grinding. Sandpapers with different grit sizes 
$(150,300,500$, and 800$)$ were used to prepare the samples. Firstly, rough sandpaper was used to smooth the surfaces of the samples. Fine sandpaper was then used to provide a smooth surface so that the boundaries of the rings could be clearly distinguished between early wood and latewood. The final diameter of the core was always slightly greater than half of the original diameter. WinDENDRO Image analysis system for tree-ring measurement (Version 2005, Regent Instruments Inc., Canada) was used to measure the width of the annual rings. The accuracy of the measuring system was $0.01 \mathrm{~mm}$. In the measurements, a preliminary cross-dating tree-ring series was carried out, and we manually eliminated errors by comparing the years in question until the width series meets the requirements, and the latewood rate of each year was obtained by calculation.

\section{Determination of tracheid morphology characteristics}

The measurement indexes of tracheid morphological characteristics included tracheid length, tracheid width, tracheid length-width ratio, tracheid cavity diameter, tracheid double wall thickness, and tracheid wall-cavity ratio was provided. 34 measurements were measured for each index, and the two maximum and two minimum values were removed. The average of 30 samples was used for further data analyses. The prepared experimental materials were soaked in a 1:1 mixture of hydrogen peroxide and glacial acetic acid to soften the cores. A rotary microtome was used to slice $30 \mu \mathrm{m}$ thick cross sectional samples. Next, samples were stained with $1 \%$ safranine for $1-2$ minutes and dehydrated with $(30 \%, 50 \%, 80 \%$, and $95 \%$ alcohol), absolute ethanol, ethanol-xylene mixture (1:1), xylene, and then placed on a glass slide for microscopic observation. Tracheid double wall thickness and tracheid cavity diameter were measured in the early and latewood in the radial direction. Small specimens were split into matchstick sizes, early wood and latewood were separately put into test tubes. Equivalent mixtures of 10\% nitric acid and $10 \%$ chromic acid were added to submerge the wood. Samples were kept at room temperature for 10-15 hours.

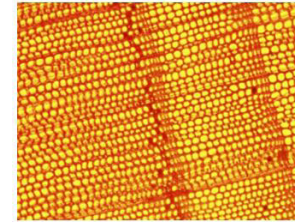

(a)

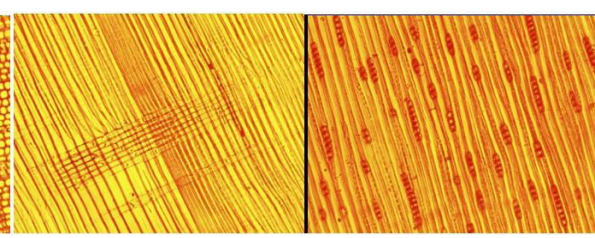

(b) (c)

Fig. 1: Microscopically pictures of measured Cupressus funebris sample: (a) cross section, (b) radial section, (c) tangential section.

After the samples were completely whitened, we poured out the mixture in the test tube and rinsed it repeatedly with distilled water. An anatomical needle was used to pull out a small amount of fibers and place it on a slide, dye with safranine solution for 1-2 minutes, add one drop of glycerin, wash off the excess dye solution, and gently arrange with the anatomical needle so that the fibers are evenly distributed. Each ring was separated three times, and the tracheid length and width were measured respectively. All tracheid morphological characteristics were measured with a Leica Application Suite X (LAS X, Leica Microsystems Inc., Buffalo Grove, IL, United States). The temporary section was enlarged $25 \mathrm{x}$ for measurement, and the permanent section was enlarged 400x times for measurement (Fig. 1). 
Processing of meteorological data

Climate factors included temperature, precipitation, sunshine, humidity and carbon dioxide concentration, etc. The meteorological data used in this experiment were from the Resource and Environment Science Data Center of the Chinese Academy of Sciences. By comparison, the climatic data of the Deyang Meteorological Station, which is near the sampling point were selected (Tab. 1). The climatic data needed for the experiment include monthly precipitation, relative humidity, sunshine percentage, average temperature and average ground temperature from 1983 to 2015 (Fig. 2).

Tab. 1: Information of meteorological stations at sampling sites.

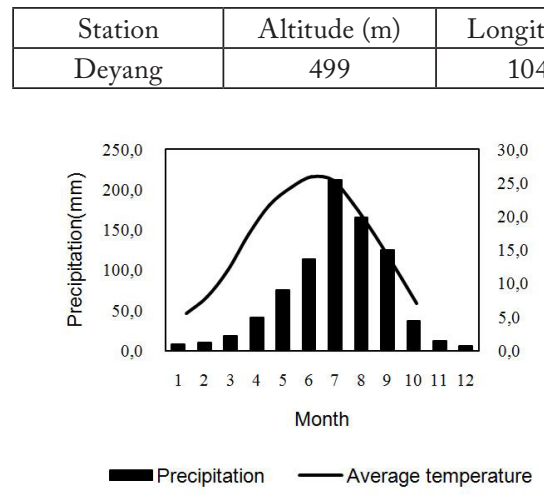

(a)

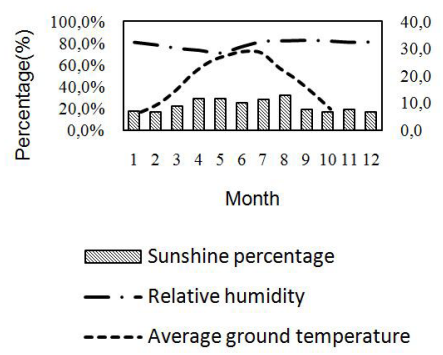

(b)

Fig. 2: Variations of: (a) precipitation (Pm) and average temperature (Tm); (b) sunshine percentage (Sp), relative humidity (Hr) and average ground temperature (Td) from 1983 to 2015.

\section{RESULTS AND DISCUSSION}

In the monitoring process of most meteorological stations, there are data missing. When the average temperature is continuously missing for more than 7 days, the missing data are fitted by a stepwise regression method ( $\mathrm{Li} 2000$ ). Through the analysis of the selected meteorological station data, the missing experimental data in the meteorological station from 1983 to 2015 accounted for less than $0.1 \%$, so the impact of meteorological data interpolation on the analysis results is very small, and the quality of meteorological data can meet the analysis requirements (Guo and Zhao 2009). Temperature has the characteristics of gradual change, but precipitation is sudden in time and space. It is a non-continuous incidental event. The interpolation method cannot be used to interpolate precipitation data. Therefore, the requirement for the integrity of precipitation data should be stricter than that of temperature (Li 2000). From 1983 to 2015, the data integrity of daily precipitation, sunshine, relative humidity and ground temperature exceeded $99.99 \%$, so the data met the requirements of experimental analysis. The radial growth of trees is not only affected by the climatic factors of that year but also that of the previous year, which is called the lag effect (Falster and Westoby 2005). To consider the lag effect on tree growth, the climatic factors of 17 months from June of the previous growth year to October were selected. 


\section{Relationship between ring width, latewood rate and climate factors}

Relationship between ring width, latewood rate and average temperature

The annual ring width chronology was negatively correlated with the average temperature in January, March, and July at $\mathrm{p}=0.05$ (Fig. 3). The early wood width chronology was significantly correlated with the average temperature in July of the previous growth year, January, March and October at the level of $\mathrm{p}=0.05$, and with the average temperature in July at the level of $\mathrm{p}=0.01$, indicating that there was a significant negative correlation between these five temperature indicators and early wood width, which is consistent with the conclusions of other researcher (Kalbarczyk and Ziemiańska 2016).

\begin{tabular}{|rcccc|}
\hline & Ring width & Early wood width & Latewood width & Latewood rate \\
\hline Tm in June of the previous growth year & 0.048 & 0.002 & 0.185 & 0.131 \\
Tm in July of the previous growth year & -0.316 & $-0.362^{*}$ & -0.1 & 0.208 \\
Tm in August of the previous growth year & 0.065 & 0.025 & 0.123 & -0.016 \\
Tm in September of the previous growth year & 0.11 & 0.039 & 0.269 & 0.142 \\
Tm in October $r$ of the previous growth year & -0.311 & -0.344 & -0.153 & 0.144 \\
Tm in November of the previous growth year & 0.052 & -0.021 & 0.234 & 0.229 \\
Tm in December of the previous growth year & 0.206 & 0.187 & 0.222 & -0.026 \\
Tm in January & $-0.405^{*}$ & $-0.399^{*}$ & -0.244 & 0.119 \\
Tm in February & -0.221 & -0.201 & -0.255 & -0.087 \\
Tm in March & $-0.423^{*}$ & $-0.442^{*}$ & -0.283 & 0.04 \\
Tm in April & -0.275 & -0.334 & -0.039 & 0.19 \\
Tm in May & -0.244 & -0.287 & -0.033 & 0.263 \\
Tm in June & -0.154 & -0.206 & 0.068 & 0.248 \\
Tm in July & $-0.423^{*}$ & $-0.467^{* *}$ & -0.147 & 0.287 \\
Tm in August & 0.16 & 0.11 & 0.193 & 0.028 \\
Tm in September & -0.077 & -0.142 & 0.167 & 0.187 \\
Tm in October & -0.347 & $-0.395^{*}$ & -0.12 & 0.184 \\
\hline
\end{tabular}

Fig. 3: Heat map of correlation coefficient between average temperature (Tm) and annual ring chronology.

\section{Relationship between ring width, latewood rate and precipitation}

The correlation coefficient values were all close to 0 , and the $\mathrm{P}$ values were all greater than 0.05 , indicating that there was no significant correlation between the ring width, early wood width, latewood width, latewood rate and 17 precipitation indicators, which is not consistent with other researcher (Fig. 4). Some research have found that temperature most negatively affected ring width in June-July of the previous growth year and April-May of the current year (Hacura et al. 2015, Ziemiańska and Kalbarczyk 2018 ).

\begin{tabular}{|rcccc|}
\hline & Ring width & Early wood width & Latewood width & Latewood rate \\
Pm in June of the previous growth year & -0.281 & -0.254 & -0.275 & -0.095 \\
Pm in July of the previous growth year & -0.041 & -0.005 & -0.195 & -0.273 \\
Pm in August of the previous growth year & 0.118 & 0.093 & 0.162 & 0.149 \\
Pm in September of the previous growth year & -0.075 & -0.012 & -0.285 & -0.236 \\
Pm in October of the previous growth year & -0.019 & 0.001 & -0.134 & -0.124 \\
Pm in November of the previous growth year & -0.05 & -0.073 & 0.069 & 0.048 \\
Pm in December of the previous growth year & -0.152 & -0.149 & -0.191 & -0.106 \\
Pm in January & 0.086 & 0.058 & 0.106 & 0.059 \\
Pm in February & 0.269 & 0.26 & 0.263 & -0.038 \\
Pm in March & 0.007 & 0.006 & 0.039 & 0.139 \\
Pm in April & 0.098 & 0.074 & 0.176 & 0.016 \\
Pm in May & 0.071 & 0.032 & 0.103 & 0.032 \\
Pm in June & -0.104 & -0.099 & -0.083 & -0.034 \\
Pm in July & 0.148 & 0.144 & 0.093 & -0.084 \\
Pm in August & 0.051 & 0.057 & 0.076 & 0.068 \\
Pm in September & -0.078 & -0.048 & -0.193 & -0.116 \\
Pm in October & -0.105 & -0.099 & -0.111 & -0.027 \\
\hline
\end{tabular}

Fig. 4: Heat map of correlation coefficient between precipitation $(\mathrm{P} m)$ and annual ring chronology. 
Relationship between ring width, latewood rate and sunshine percentage

C. funebris is a light-loving tree. In July, the cell activity of trees is vigorous. The appropriate light is conducive to photosynthesis and energy storage. However, if the intensity of sunlight increases, the photosynthesis is intense, which causes a large demand for water and temperature. From Fig. 5, it can be seen that there is a negative correlation between the annual ring width, early wood width, and the average temperature in July.

\begin{tabular}{|c|c|c|c|c|}
\hline & Ring width & Early wood width & Latewood width & Latewood rate \\
\hline $\mathrm{Sp}$ in June of the previous growth year & 0.26 & 0.261 & 0.206 & -0.004 \\
\hline Sp in July of the previous growth year & -0.208 & -0.192 & -0.125 & 0.216 \\
\hline Sp in August of the previous growth year & 0.05 & 0.067 & -0.017 & -0.036 \\
\hline Sp in September of the previous growth year & 0.247 & 0.202 & $0.381^{*}$ & 0.264 \\
\hline Sp in October of the previous growth year & -0.226 & -0.212 & -0.193 & 0.047 \\
\hline Sp in November of the previous growth year & -0.069 & -0.036 & -0.186 & -0.044 \\
\hline Sp in December of the previous growth year & -0.274 & -0.226 & $-0.409^{*}$ & -0.222 \\
\hline $\mathrm{Sp}$ in January & -0.135 & -0.109 & -0.157 & 0.041 \\
\hline Sp in February & -0.208 & -0.177 & -0.237 & 0.076 \\
\hline $\mathrm{Sp}$ in March & -0.136 & -0.127 & -0.149 & 0.019 \\
\hline Sp in April & -0.174 & -0.201 & -0.024 & 0.264 \\
\hline Sp in May & -0.157 & -0.16 & -0.079 & 0.12 \\
\hline Sp in June & 0.189 & 0.166 & 0.237 & 0.122 \\
\hline $\mathrm{Sp}$ in July & $-0.366^{*}$ & $-0.354^{*}$ & -0.218 & 0.299 \\
\hline $\mathrm{Sp}$ in August & 0.176 & 0.186 & 0.07 & -0.027 \\
\hline Sp in September & 0.21 & 0.155 & $0.372^{*}$ & 0.299 \\
\hline $\mathrm{Sp}$ in October & -0.277 & -0.249 & -0.306 & -0.021 \\
\hline
\end{tabular}

Fig. 5: Heat map of correlation coefficient between sunshine percentage (Sp) and annual ring chronology.

Therefore, the sunshine percentage in July has a limited effect on the increase of the annual ring width and early wood width. September of the previous growth year and December of the previous growth year had different effects on the growth of latewood width in the same year. In September, the life activities of trees decreased. Adequate light was conducive to the enhancement of photosynthesis, prolonging the growth period of trees, thus promoting the increase of latewood width (Nabais et al. 2014, Begum et al. 2018).

\section{Relationship between ring width, latewood rate and relative humidity}

C. funebris is suitable to grow in warm and humid conditions. The relative humidity in March and April is favorable for the early development of trees. In July, the cambium activity is vigorous, and the humid environment accelerates the growth and division of cells. At the same time, it can store a large amount of water and promote the increase of the width of latewood. In October, the relative humidity is high, and the growth period of trees is prolonged (Fig. 6). In addition, the width of the ring was also affected by the lag of relative humidity in July, October, and December of the previous growth year (Fritts 1976). 


\begin{tabular}{|rcccc|}
\hline & Ring width & Early wood width & Latewood width & Latewood rate \\
\hline Hr in June of the previous growth year & -0.056 & -0.024 & -0.126 & -0.011 \\
Hr in July of the previous growth year & $0.472^{* *}$ & $0.493^{* * *}$ & 0.272 & -0.204 \\
Hr in August of the previous growth year & 0.303 & 0.31 & 0.241 & 0.059 \\
Hr in September of the previous growth year & 0.147 & 0.215 & -0.135 & -0.291 \\
Hr in October of the previous growth year & $0.43^{* *}$ & $0.452^{* * *}$ & 0.174 & -0.287 \\
Hr in November of the previous growth year & 0.349 & 0.335 & 0.284 & -0.008 \\
Hr in December of the previous growth year & $0.469^{* *}$ & $0.41^{*}$ & $0.618^{* *}$ & 0.298 \\
Hr in January & 0.063 & 0.063 & 0.076 & 0.167 \\
Hr in February & 0.238 & 0.194 & $0.38^{*}$ & 0.278 \\
Hr in March & 0.272 & 0.227 & $0.422^{* *}$ & 0.303 \\
Hr in April & $0.425^{*}$ & $0.459^{* * *}$ & 0.267 & -0.083 \\
Hr in May & 0.307 & 0.28 & 0.314 & 0.109 \\
Hr in June & 0.181 & 0.197 & 0.108 & -0.014 \\
Hr in July & $0.645^{* *}$ & $0.63^{* *}$ & $0.537^{* * *}$ & -0.053 \\
Hr in August & 0.289 & 0.277 & 0.337 & 0.168 \\
Hr in September & 0.263 & 0.317 & 0.018 & -0.23 \\
Hr in October & $0.396^{*}$ & $0.371^{*}$ & 0.349 & -0.008 \\
\hline
\end{tabular}

Fig. 6: Heat map of correlation coefficient between relative humidity $(\mathrm{Hr})$ and annual ring chronology.

\section{Relationship between ring width, latewood rate and average ground temperature}

The annual rings width is limited by the average ground temperature in January, March and July, and the early wood width is limited by the average ground temperature in January, March and October, which is basically consistent with the results of the above analysis. In addition, the early wood width is limited by the average ground temperature in July of the previous growth year (Fig. 7). Therefore, it can be known that the average ground temperature in July and July of the previous growth year can promote the latewood rate (Nabais et al. 2014).

\begin{tabular}{|rcccc|}
\hline & Ring width & Early wood width & Latewood width & Latewood rate \\
\hline Td in June of the previous growth year & 0.189 & 0.155 & 0.278 & 0.135 \\
Td in July of the previous growth year & -0.319 & $-0.371^{*}$ & 0.002 & $0.466^{* *}$ \\
Td in August of the previous growth year & 0.049 & 0.027 & 0.104 & 0.065 \\
Td in September of the previous growth year & 0.163 & 0.214 & -0.065 & -0.293 \\
Td in October of the previous growth year & -0.319 & -0.341 & -0.185 & 0.166 \\
Td in November of the previous growth year & 0.045 & -0.03 & 0.203 & 0.227 \\
Td in December of the previous growth year & 0.104 & 0.177 & -0.157 & $-0.357^{*}$ \\
Td in January & $-0.397^{*}$ & $-0.377^{*}$ & -0.316 & 0.008 \\
Td in February & -0.238 & -0.215 & -0.284 & -0.078 \\
Td in March & $-0.376^{*}$ & $-0.394^{*}$ & -0.249 & 0.056 \\
Td in April & -0.266 & -0.317 & -0.058 & 0.173 \\
Td in May & -0.21 & -0.216 & -0.112 & 0.11 \\
Td in June & 0.062 & 0.018 & 0.225 & 0.25 \\
Td in July & $-0.425^{*}$ & $-0.459^{* *}$ & -0.107 & $0.442^{*}$ \\
Td in August & 0.129 & 0.102 & 0.139 & 0.068 \\
Td in September & 0.229 & 0.222 & 0.155 & -0.132 \\
Td in October & -0.316 & $-0.355^{*}$ & -0.139 & 0.171 \\
\hline
\end{tabular}

Fig. 7: Heat map of correlation coefficient between average ground temperature (Td) and annual ring chronology.

\section{Relationship between tracheid morphological characteristics and climate factors}

Relationship between tracheid morphological characteristics and average temperature

When the average temperature is high in March and April, the trees consume less nutrients stored by themselves, and these can help the trees grow and develop, which is conducive to tracheid elongation (Fig. 8). Nutrients and precipitation are sufficient for tree growth in July, the higher the average temperature, the more vigorous the growth of trees, which is consistent with the conclusions of other researcher (Vichrová et al. 2013). 


\begin{tabular}{|c|c|c|c|c|c|c|c|c|c|c|c|c|}
\hline & $\begin{array}{l}\text { Early } \\
\text { wood } \\
\text { tracheid } \\
\text { length }\end{array}$ & $\begin{array}{l}\text { Latew ood } \\
\text { tracheid } \\
\text { length }\end{array}$ & $\begin{array}{c}\text { E.W. } \\
\text { tracheid } \\
\text { width }\end{array}$ & $\begin{array}{c}\text { L.W. } \\
\text { tracheid } \\
\text { width }\end{array}$ & $\begin{array}{l}\text { E.W. } \\
\text { tracheid } \\
\text { length- } \\
\text { width ratio }\end{array}$ & $\begin{array}{l}\text { L.W. } \\
\text { tracheid } \\
\text { length- } \\
\text { width ratio }\end{array}$ & $\begin{array}{l}\text { E.W. } \\
\text { tracheid } \\
\text { cavity } \\
\text { diameter }\end{array}$ & $\begin{array}{l}\text { L.W. } \\
\text { tracheid } \\
\text { cavity } \\
\text { diameter }\end{array}$ & $\begin{array}{c}\text { E.W. } \\
\text { tracheid } \\
\text { double } \\
\text { wall } \\
\text { thickness }\end{array}$ & $\begin{array}{l}\text { L.W. } \\
\text { tracheid } \\
\text { double } \\
\text { wall } \\
\text { thickness }\end{array}$ & $\begin{array}{c}\text { E.W. } \\
\text { tracheid } \\
\text { wall-canity } \\
\text { ratio }\end{array}$ & $\begin{array}{l}\text { L.W. } \\
\text { tracheid } \\
\text { wall-cavity } \\
\text { ratio }\end{array}$ \\
\hline Tm in June of the previous growth year & 0.046 & -0.043 & 0.077 & 0.182 & -0.016 & -0.067 & 0.199 & 0.243 & 0.016 & -0.003 & -0.08 & -0.116 \\
\hline Tm in July of the previous growth year & $0.458^{* *}$ & $0.499 * *$ & 0.099 & 0.329 & 0.29 & 0.274 & 0.221 & 0.044 & -0.213 & 0.081 & 0.18 & 0.031 \\
\hline Tm in August of the previous growth year & 0.031 & -0.024 & -0.067 & 0.27 & 0.108 & -0.173 & 0.134 & -0.063 & -0.1 & 0.194 & 0.185 & 0.165 \\
\hline Tm in September of the previous growth & 0.337 & 0.135 & 0.326 & $0.354^{*}$ & 0.005 & -0.034 & $0.35^{*}$ & 0.24 & -0.288 & -0.16 & 0.025 & -0.224 \\
\hline Tm in October of the previous growth year & 0.467 & 0.47 & 0.093 & 0.277 & 0.269 & 0.308 & 0.098 & -0.129 & $-0.469 * *$ & -0.029 & 0.193 & 0.103 \\
\hline Im in November of the previous growth & 0.242 & 0.052 & 0.196 & 0.258 & 0.069 & -0.07 & 0.063 & 0.034 & -0.075 & -0.008 & 0.099 & 0.009 \\
\hline Im in December of the previous growth & -0.074 & -0.122 & 0.149 & -0.034 & -0.195 & -0.125 & 0.33 & $0.36^{*}$ & 0.111 & -0.173 & -0.189 & -0.33 \\
\hline Tm in January & 0.053 & 0.215 & -0.171 & 0.183 & 0.108 & 0.225 & 0.034 & -0.095 & -0.287 & 0.187 & -0.121 & 0.172 \\
\hline Tm in February & 0.243 & $0.393^{*}$ & -0.057 & 0.072 & 0.232 & 0.332 & 0.094 & -0.013 & -0.098 & -0.007 & 0.2 & -0.001 \\
\hline Tm in March & $0.469^{\text {thin }}$ & 0.559 ** & -0.162 & 0.112 & $0.495^{* *}$ & $0.48^{\text {*** }}$ & 0.213 & -0.074 & -0.241 & 0.198 & 0.329 & 0.176 \\
\hline Tm in April & $0.441^{*}$ & $0.362^{*}$ & -0.081 & 0.349 & $0.532^{* *}$ & 0.202 & -0.005 & -0.29 & -0.161 & $0.429^{*}$ & $0.441^{*}$ & $0.437^{*}$ \\
\hline Tm in May & 0.335 & 0.263 & -0.097 & $0.37^{*}$ & 0.319 & 0.067 & -0.182 & -0.29 & -0.067 & 0.382 & 0.295 & $0.399^{*}$ \\
\hline Tm in June & 0.126 & 0.129 & -0.086 & 0.223 & 0.157 & 0.016 & 0.114 & 0.039 & 0.113 & 0.28 & 0.036 & 0.117 \\
\hline Tm in July & $0.539 * *$ & $0.49)^{* * *}$ & -0.055 & 0.337 & $0.446^{*}$ & 0.28 & 0.008 & -0.139 & -0.228 & 0.268 & 0.274 & 0.25 \\
\hline Tm in August & 0.14 & -0.038 & 0.016 & 0.258 & 0.1 & -0.193 & 0.04 & 0.024 & 0.044 & 0.13 & 0.221 & 0.072 \\
\hline Tm in September & 0.225 & 0.196 & 0.205 & 0.306 & 0.084 & 0.04 & $0.391^{*}$ & 0.219 & -0.273 & -0.02 & -0.048 & -0.131 \\
\hline $\mathrm{Tm}$ in October & $0.463^{* *}$ & $0.424^{*}$ & -0.052 & $0.353^{*}$ & $0.453 *$ & 0.261 & -0.02 & -0.303 & $-0.423^{*}$ & 0.297 & 0.322 & $0.371^{\circ}$ \\
\hline
\end{tabular}

Fig. 8: Heat map of correlation coefficient between average temperature (Tm) and tracheid morphological characteristics chronology.

The high average temperature in September and October prolonged the growth time of cells, thus promoting the increase of tracheid length and early wood tracheid cavity diameter, respectively. From the effect of average temperature on tracheid length and width, the tracheid length-width ratio corresponds to average temperature (Olano et al. 2012). High average temperature in December was beneficial to the increase of latewood cavity diameter, while high average temperature in October was not conducive to the formation of early wood cell wall. The higher average temperature in April and May is conducive to the formation of cell wall of latewood.

\section{Relationship between tracheid morphological characteristics and precipitation}

There was a significant negative correlation between the early wood tracheid length, latewood tracheid length, latewood tracheid length-width ratio, and precipitation in February at the level of $\mathrm{p}=0.05$ (Fig. 9).

\begin{tabular}{|c|c|c|c|c|c|c|c|c|c|c|c|c|}
\hline & $\begin{array}{l}\text { Early } \\
\text { wood } \\
\text { tracheid } \\
\text { length }\end{array}$ & $\begin{array}{l}\text { Latervood } \\
\text { tracheid } \\
\text { length }\end{array}$ & $\begin{array}{l}\text { E.W. } \\
\text { tracheid } \\
\text { width }\end{array}$ & $\begin{array}{l}\text { L.W. } \\
\text { tracheid } \\
\text { width }\end{array}$ & $\begin{array}{l}\text { E.W. } \\
\text { tracheid } \\
\text { length- } \\
\text { width ratio }\end{array}$ & $\begin{array}{l}\text { L.W. } \\
\text { tracheid } \\
\text { length- } \\
\text { width ratio }\end{array}$ & $\begin{array}{c}\text { E.W. } \\
\text { tracheid } \\
\text { cavity } \\
\text { diameter }\end{array}$ & $\begin{array}{l}\text { L.W. } \\
\text { tracheid } \\
\text { cavity } \\
\text { diameter }\end{array}$ & $\begin{array}{l}\text { E.W. } \\
\text { tracheid } \\
\text { double } \\
\text { wall } \\
\text { thickness }\end{array}$ & $\begin{array}{l}\text { L.W. } \\
\text { tracheid } \\
\text { double } \\
\text { wall } \\
\text { thickness }\end{array}$ & $\begin{array}{c}\text { E.W. } \\
\text { tracheid } \\
\text { wall-cavity } \\
\text { ratio }\end{array}$ & $\begin{array}{c}\text { L.W. } \\
\text { tracheid } \\
\text { wall-cavity } \\
\text { ratio }\end{array}$ \\
\hline Pm in June of the previous growth year & -0.083 & 0.063 & -0.326 & -0.143 & 0.184 & 0.277 & 0.123 & -0.05 & 0.079 & 0.227 & -0.003 & 0.133 \\
\hline Pm in July of the previous growth year & -0.255 & -0.159 & -0.331 & -0.207 & 0.089 & 0.098 & 0.026 & -0.037 & 0.158 & 0.159 & 0.059 & 0.14 \\
\hline Pm in August of the previous growth year & 0.101 & -0.03 & 0.225 & -0.033 & -0.047 & -0.056 & -0.153 & -0.039 & 0.02 & -0.112 & -0.025 & -0.052 \\
\hline Pm in September of the previous growth & -0.026 & 0.172 & 0.12 & -0.183 & -0.116 & 0.209 & 0.079 & 0.1 & -0.206 & $-0.377^{*}$ & -0.035 & -0.27 \\
\hline $\mathrm{Pm}$ in October of the previous growth year & 0.238 & 0.164 & 0.054 & -0.082 & 0.126 & 0.167 & 0.027 & 0.02 & 0.117 & -0.087 & 0.296 & -0.04 \\
\hline Pm in November of the previous growth & 0.052 & -0.043 & -0.25 & 0.118 & 0.107 & -0.029 & 0.03 & -0.078 & -0.048 & 0.244 & -0.003 & 0.17 \\
\hline Pm in December of the previous growth & 0.168 & 0.174 & -0.223 & 0.021 & 0.301 & 0.163 & -0.058 & -0.227 & 0.021 & 0.26 & $0.363^{*}$ & 0.281 \\
\hline Pm in January & 0.201 & 0.101 & 0.199 & 0.059 & -0.003 & 0.016 & 0.051 & -0.013 & -0.13 & -0.161 & 0.096 & -0.067 \\
\hline Pm in February & $-0.363^{*}$ & $-0.423^{*}$ & -0.107 & -0.057 & -0.208 & $-0.36^{*}$ & 0.036 & 0.11 & 0.22 & 0.102 & -0.246 & -0.049 \\
\hline Pmin March & -0.101 & -0.082 & 0.135 & 0.183 & -0.172 & -0.172 & -0.168 & -0.038 & 0.01 & 0.035 & -0.078 & 0.04 \\
\hline Pm in April & 0.015 & 0.005 & 0.056 & 0.08 & -0.031 & -0.067 & 0.138 & 0.099 & -0.245 & -0.073 & -0.137 & -0.087 \\
\hline Pm in May & 0.235 & 0.112 & 0.289 & 0.138 & 0.011 & -0.02 & 0.161 & 0.065 & -0.295 & -0.2 & 0.101 & -0.116 \\
\hline Pmin June & -0.054 & 0.023 & -0.081 & -0.092 & 0.018 & 0.12 & 0.092 & -0.002 & -0.064 & 0.059 & -0.062 & 0.04 \\
\hline Pm in July & -0.126 & -0.216 & -0.055 & -0.023 & -0.052 & -0.126 & 0.024 & -0.037 & 0.163 & 0.115 & 0.067 & 0.067 \\
\hline Pm in August & 0.06 & -0.009 & 0.056 & -0.145 & -0.043 & 0.001 & -0.051 & 0.062 & 0.143 & -0.134 & -0.087 & -0.126 \\
\hline Pm in September & 0.108 & 0.167 & 0.086 & -0.074 & 0.035 & 0.188 & -0.048 & -0.054 & -0.121 & -0.154 & 0.087 & -0.027 \\
\hline Pmin October & 0.093 & 0.181 & -0.018 & 0.136 & 0.123 & 0.151 & 0.14 & 0.085 & -0.009 & -0.002 & 0.153 & -0.061 \\
\hline
\end{tabular}

Fig. 9: Heat map of correlation coefficient between precipitation $(\mathrm{Pm})$ and tracheid morphological characteristics chronology. 
In February, trees are in dormant period, and the precipitation is high, which reduces the soil temperature. To a certain extent, it affects the respiration of tree roots and nutrient uptake by roots, thus inhibiting the increase of tracheid length and reducing the latewood tracheid lengthwidth ratio. (Jonsson et al. 2002).

\section{Relationship between tracheid morphological characteristics and sunshine percentage}

The sunshine percentage in September is beneficial to the radial growth of trees, so the larger the sunshine percentage, the smaller the tracheid length-width ratio. High sunshine intensity can provide sufficient light and suitable temperature conditions for photosynthesis, which is conducive to the growth of cell walls, thus inhibiting the increase of cavity diameter in the same period. Because the sunshine percentage in April has an inhibitory effect on the cavity diameter of latewood, the larger the sunshine percentage, the larger the wall-cavity ratio of latewood (Yasue et al. 2000, Begum et al. 2018).

\begin{tabular}{|c|c|c|c|c|c|c|c|c|c|c|c|c|}
\hline & $\begin{array}{c}\text { Early } \\
\text { wood } \\
\text { tracheid } \\
\text { length }\end{array}$ & $\begin{array}{c}\text { Latewood } \\
\text { tracheid } \\
\text { length }\end{array}$ & $\begin{array}{c}\text { E.W. } \\
\text { tracheid } \\
\text { width }\end{array}$ & $\begin{array}{c}\text { L.W. } \\
\text { tracheid } \\
\text { width }\end{array}$ & $\begin{array}{l}\text { E.W. } \\
\text { tracheid } \\
\text { length- } \\
\text { width ratio }\end{array}$ & $\begin{array}{l}\text { L.W. } \\
\text { tracheid } \\
\text { length- } \\
\text { width ratio }\end{array}$ & $\begin{array}{c}\text { E.W. } \\
\text { tracheid } \\
\text { cavity } \\
\text { diameter }\end{array}$ & $\begin{array}{l}\text { L.W. } \\
\text { tracheid } \\
\text { cavity } \\
\text { diameter }\end{array}$ & $\begin{array}{l}\text { E.W. } \\
\text { tracheid } \\
\text { double } \\
\text { wall } \\
\text { thickness }\end{array}$ & $\begin{array}{l}\text { L.W. } \\
\text { tracheid } \\
\text { double } \\
\text { wall } \\
\text { thickness }\end{array}$ & $\begin{array}{l}\text { E.W. } \\
\text { tracheid } \\
\text { wall-cavity } \\
\text { ratio }\end{array}$ & $\begin{array}{l}\text { L.W. } \\
\text { tracheid } \\
\text { wall-cavity } \\
\text { ratio }\end{array}$ \\
\hline Sp in June of the previous growth year & $-0.351^{*}$ & $-0.366^{*}$ & 0.017 & -0.192 & -0.263 & -0.214 & -0.043 & 0.216 & 0.262 & -0.155 & -0.258 & -0.189 \\
\hline Sp in July of the previous growth year & -0.139 & 0.062 & 0.007 & 0.037 & -0.128 & 0.028 & -0.172 & -0.033 & 0.067 & 0.014 & -0.226 & 0.016 \\
\hline Sp in August of the previous growth year & .0 .244 & -0.187 & -0.17 & -0.058 & -0.052 & -0.165 & -0.247 & -0.224 & 0.121 & 0.151 & 0.004 & 0.21 \\
\hline Sp in September of the previous growth year & -0.111 & -0.239 & 0.341 & 0.227 & -0.327 & $-0.385^{*}$ & -0.068 & 0.08 & -0.211 & -0.188 & -0.301 & -0.129 \\
\hline Sp in October of the previous growth year & 0.055 & 0.154 & -0.133 & 0.03 & 0.14 & 0.097 & -0.046 & -0.098 & 0.06 & 0.144 & 0.075 & 0.144 \\
\hline Sp in November of the previous growth year & -0.039 & 0.076 & 0.002 & -0.145 & 0.017 & 0.177 & -0.179 & -0.095 & 0.216 & -0.033 & 0.096 & 0.02 \\
\hline Sp in December of the previous growth year & 0.068 & 0.236 & -0.273 & -0.123 & 0.219 & 0.328 & 0.034 & -0.181 & -0.029 & 0.174 & 0.22 & 0.191 \\
\hline Sp in January & -0.055 & 0.004 & -0.139 & 0.015 & 0.05 & 0.03 & -0.289 & -0.322 & 0.061 & 0.214 & 0.121 & 0.283 \\
\hline Sp in February & 0.142 & 0.282 & 0.118 & -0.063 & 0.016 & 0.264 & -0.188 & -0.13 & -0.134 & -0.18 & -0.006 & -0.014 \\
\hline Sp in March & $0.37^{*}$ & 0.34 & 0.121 & 0.131 & 0.12 & 0.19 & -0.052 & -0.108 & -0.273 & -0.12 & 0.24 & -0.008 \\
\hline Sp in April & 0.091 & 0.11 & 0.017 & 0.265 & 0.151 & -0.027 & $-0.353^{*}$ & $-0.368^{*}$ & -0.128 & 0.265 & 0.133 & $0.388^{4}$ \\
\hline Sp in May & -0.032 & 0.01 & -0.191 & 0.016 & 0.088 & 0.037 & -0.17 & -0.187 & 0.038 & 0.248 & -0.018 & 0.252 \\
\hline Sp in June & -0.272 & -0.266 & 0.037 & -0.099 & -0.287 & -0.262 & 0.125 & 0.312 & 0.33 & -0.045 & -0.347 & -0.237 \\
\hline Sp in July & 0.069 & 0.161 & -0.078 & -0.018 & 0.148 & 0.148 & $-0.393^{*}$ & -0.28 & 0.035 & 0.231 & -0.021 & 0.298 \\
\hline Sp in August & -0.147 & -0.202 & -0.034 & -0.105 & -0.088 & -0.205 & -0.261 & -0.09 & 0.189 & 0.014 & 0.037 & 0.06 \\
\hline Sp in September & -0.128 & -0.175 & 0.322 & 0.194 & $-0.357^{*}$ & $-0.36^{*}$ & -0.051 & 0.08 & -0.181 & -0.173 & -0.338 & -0.146 \\
\hline Sp in October & 0.119 & 0.242 & -0.192 & -0.05 & 0.269 & 0.274 & -0.199 & -0.239 & 0.017 & 0.227 & 0.231 & 0.258 \\
\hline
\end{tabular}

Fig. 10: Heat map of correlation coefficient between sunshine percentage (Sp) and tracheid morphological characteristics chronology.

\begin{tabular}{|c|c|c|c|c|c|c|c|c|c|c|c|c|}
\hline & $\begin{array}{l}\text { Early } \\
\text { wood } \\
\text { tracheid } \\
\text { length }\end{array}$ & $\begin{array}{c}\text { Latewood } \\
\text { tracheid } \\
\text { length }\end{array}$ & $\begin{array}{c}\text { E.W. } \\
\text { tracheid } \\
\text { width }\end{array}$ & $\begin{array}{c}\text { L.W. } \\
\text { tracheid } \\
\text { width }\end{array}$ & $\begin{array}{l}\text { E.W. } \\
\text { tracheid } \\
\text { length- } \\
\text { with ratio }\end{array}$ & $\begin{array}{l}\text { L.W. } \\
\text { tracheid } \\
\text { length- } \\
\text { width ratio }\end{array}$ & $\begin{array}{l}\text { E.W. } \\
\text { tracheid } \\
\text { cavity } \\
\text { diameter }\end{array}$ & $\begin{array}{l}\text { L.W. } \\
\text { tracheid } \\
\text { cavity } \\
\text { diameter }\end{array}$ & $\begin{array}{c}\text { E.W. } \\
\text { tracheid } \\
\text { double } \\
\text { wall } \\
\text { thickness }\end{array}$ & $\begin{array}{c}\text { L.W. } \\
\text { tracheid } \\
\text { double } \\
\text { wall } \\
\text { thickness }\end{array}$ & $\begin{array}{c}\text { E.W. } \\
\text { tracheid } \\
\text { wall-cavity } \\
\text { tatio }\end{array}$ & $\begin{array}{c}\text { L.W. } \\
\text { tracheid } \\
\text { wall-cavity } \\
\text { ratio }\end{array}$ \\
\hline Hr in June of the previous growth year & 0.022 & 0.106 & 0.007 & -0.108 & $-0,006$ & 0.072 & -0.265 & -0.257 & -0.077 & -0.055 & 0.019 & 0.09 \\
\hline Hr in July of the previous growth year & $-0.458^{* *}$ & $-0.534 * *$ & 0.013 & -0.258 & $-0.42^{k}$ & $-0.38 \%$ & -0.058 & 0.167 & 0.188 & -0.234 & -0.302 & -0.232 \\
\hline Hr in August of the previous growth year & -0.239 & -0.285 & 0.274 & -0.157 & $-0.428 *$ & -0.222 & -0.094 & 0.206 & 0.116 & -0.335 & $-0.366^{*}$ & -0.334 \\
\hline $\mathrm{Hr}$ in September of the previous growth year & -0.3 & -0.181 & -0.055 & -0.347 & -0.267 & 0.002 & -0.07 & 0.073 & 0.192 & -0.22 & -0.11 & -0.192 \\
\hline Hr in October of the previous growth year & -0.262 & -0.267 & 0.244 & -0.161 & $-0.423^{*}$ & -0.197 & 0.285 & $0.451^{* *}$ & 0.135 & $-0.454 * *$ & -0.152 & $-0.512^{* *}$ \\
\hline Hr in November of the previous growth year & -0.053 & -0.221 & 0.317 & 0.005 & $-0.352 *$ & -0.276 & 0.067 & 0.249 & 0.002 & $-0.366^{*}$ & -0.163 & -0.342 \\
\hline Hr in December of the previous growth year & $-0.403^{*}$ & $-0.549 * *$ & $0.428^{*}$ & 0.138 & $-0.695^{\mathrm{k} k}$ & $-0.619^{\text {** }}$ & 0.065 & $0.387^{*}$ & -0.067 & $-0.383^{*}$ & $-0.667^{* *}$ & $-0.418^{4}$ \\
\hline Hr in January & -0.133 & -0.087 & 0.144 & -0.198 & -0.221 & -0.049 & -0.156 & 0.132 & 0.2 & -0.205 & -0.261 & -0.196 \\
\hline Hr in February & -0.345 & $-0.414^{*}$ & 0.132 & 0.075 & $-0.359 *$ & $-0.499 * *$ & -0.087 & 0.15 & 0.167 & 0.018 & $-0.413 *$ & -0.088 \\
\hline $\mathrm{Hr}$ in March & $-0.398^{4}$ & $-0.462^{* *}$ & 0.196 & 0.096 & $-0.424^{*}$ & $-0.475^{k *}$ & -0.123 & 0.122 & 0.11 & -0.029 & $-0.452^{* *}$ & -0.09 \\
\hline Hr in April & $-0.498^{* *}$ & $-0.496^{* *}$ & 0.161 & -0.347 & $-0.542^{* *}$ & -0.337 & -0.05 & 0.297 & 0.279 & $-0.368^{*}$ & $-0.485 * *$ & $-0.42^{*}$ \\
\hline Hr in May & -0.144 & -0.246 & $0.387 *$ & 0.007 & $-0.382 *$ & -0.311 & -0.008 & 0.163 & -0.107 & -0.346 & -0.275 & -0.281 \\
\hline Hr in June & -0.034 & -0.16 & 0.254 & .0 .096 & -0.2 & -0.125 & -0.224 & -0.089 & -0.187 & -0.284 & -0.085 & -0.088 \\
\hline $\mathrm{Hr}$ in July & $-0.449^{* *}$ & $-0.631 * *$ & 0.331 & -0.064 & $-0.646^{k *}$ & $-0.583 * *$ & 0.095 & $0.363^{*}$ & 0.108 & $-0.425 *$ & $-0.437^{*}$ & $-0.467^{* *}$ \\
\hline $\mathrm{Hr}$ in August & -0.285 & -0.346 & $0.354^{*}$ & -0.067 & $-0.489^{* * *}$ & -0.312 & 0.02 & 0.273 & 0.046 & $-0.364^{*}$ & -0.472 ** & $-0.371^{*}$ \\
\hline Hr in September & -0.296 & -0.307 & 0.113 & -0.216 & -0.305 & -0.169 & -0.03 & 0.153 & 0.133 & -0.304 & -0.125 & -0.249 \\
\hline Hr in October & -0.269 & -0.315 & $0.413^{*}$ & 0.109 & $-0.497^{* *}$ & -0.372 & 0.389 & $0.547^{* *}$ & 0.012 & $-0.448 * *$ & -0.348 & $-0.56^{k *}$ \\
\hline
\end{tabular}

Fig. 11: Heat map of correlation coefficient between relative humidity $(\mathrm{Hr})$ and tracheid morphological characteristics chronology. 
Relationship between tracheid morphological characteristics and relative humidity

From Fig. 11, it can be seen that high relative humidity is conducive to the radial growth of trees. It can also be concluded that relative humidity can inhibit tracheid length, as well as promote the increase of tracheid width. The higher the relative humidity in July and October, the more abundant the water vapor, the greater the cell viability, the faster the tree grows, and the faster the cavity diameter increases. At the same time, relative humidity promoted tracheid width and diameter, but inhibited tracheid wall thickness, and the corresponding latewood wallto-cavity ratio was smaller (Yasue et al. 2000, Nabais et al. 2014).

\section{Relationship between tracheid morphological characteristics and average ground temperature}

The relationship between tracheid length and average ground temperature, and the relationship between tracheid width and average temperature were basically the same for the same reason (Fig. 12).

\begin{tabular}{|c|c|c|c|c|c|c|c|c|c|c|c|c|}
\hline & $\begin{array}{c}\text { Early } \\
\text { wood } \\
\text { tracheid } \\
\text { length }\end{array}$ & $\begin{array}{c}\text { Latewood } \\
\text { tracheid } \\
\text { lenght }\end{array}$ & $\begin{array}{c}\text { E.W. } \\
\text { tracheid } \\
\text { widh }\end{array}$ & $\begin{array}{l}\text { L.W. } \\
\text { tracheid } \\
\text { width }\end{array}$ & $\begin{array}{l}\text { E.W. } \\
\text { tracheid } \\
\text { length- } \\
\text { width ratio }\end{array}$ & $\begin{array}{l}\text { L.W. } \\
\text { tracheid } \\
\text { length- } \\
\text { width ratio }\end{array}$ & $\begin{array}{l}\text { E.W. } \\
\text { tracheid } \\
\text { cavity } \\
\text { diameter }\end{array}$ & $\begin{array}{l}\text { L.W. } \\
\text { tracheid } \\
\text { cavity } \\
\text { diameter }\end{array}$ & $\begin{array}{l}\text { E.W. } \\
\text { tracheid } \\
\text { double } \\
\text { wall } \\
\text { thickness }\end{array}$ & $\begin{array}{l}\text { L.W. } \\
\text { tracheid } \\
\text { double } \\
\text { wall } \\
\text { thickness }\end{array}$ & $\begin{array}{c}\text { E.W. } \\
\text { tracheid } \\
\text { wall-carity } \\
\text { ratio }\end{array}$ & $\begin{array}{c}\text { L.W. } \\
\text { tracheid } \\
\text { wall-cavity } \\
\text { ratio }\end{array}$ \\
\hline Td in June of the previous gr onth year & -0.139 & -0.239 & 0.091 & 0.053 & -0.182 & -0.227 & 0.039 & 0.22 & 0.138 & -0.054 & -0.204 & .0 .137 \\
\hline Td in July of the previous growth year & $0.394^{*}$ & $0.418^{*}$ & 0.188 & 0.292 & 0.143 & 0.166 & -0.095 & -0.09 & -0.198 & 0.055 & -0.025 & 0.079 \\
\hline Id in August of the previous growth year & -0.057 & -0.088 & -0.098 & 0.151 & 0.023 & -0.192 & -0.096 & -0.142 & 0.013 & 0.172 & 0.071 & 0.191 \\
\hline Td in September of the previous growth year & -0.167 & -0.136 & -0.07 & -0.276 & -0.098 & 0.038 & 0.019 & 0.085 & -0.043 & -0.266 & -0.074 & -0.187 \\
\hline Td in October of the previous growth year & $0.462^{* *}$ & $0.471^{1 / k}$ & 0.098 & 0.235 & 0.28 & 0.292 & -0.068 & -0.25 & $-0.457^{* *}$ & -0.03 & 0.228 & 0.173 \\
\hline Td in November of the previous gr owth year & 0.303 & 0.087 & 0.235 & 0.281 & 0.126 & -0.054 & -0.028 & -0.086 & -0.118 & 0.009 & 0.224 & 0.098 \\
\hline Td in December of the previous growth year & -0.133 & -0.083 & -0.058 & $-0.386^{*}$ & -0.057 & 0.13 & 0.019 & 0.033 & 0.076 & -0.18 & 0.015 & -0.157 \\
\hline Td in January & 0.041 & 0.208 & -0.21 & 0.118 & 0.142 & 0.267 & 0.044 & -0.11 & -0.282 & 0.16 & -0.044 & 0.18 \\
\hline Td in February & 0.296 & $0.434^{*}$ & -0.026 & 0.072 & 0.242 & $0.356^{*}$ & 0.024 & -0.083 & -0.154 & -0.039 & 0.249 & 0.029 \\
\hline Td in March & $0.47 * *$ & $0.537^{* *}$ & -0.101 & 0.111 & $0.434^{*}$ & $0.43 \%^{*}$ & 0.177 & -0.071 & -0.244 & 0.128 & 0.311 & 0.133 \\
\hline Id in April & $0.365^{*}$ & 0.277 & -0.163 & 0.305 & $0.541^{* *}$ & 0.154 & -0.163 & $-0.436^{*}$ & -0.149 & $0.498 * *$ & $0.467^{* *}$ & $0.567^{*} *$ \\
\hline Td in May & 0.147 & 0.119 & -0.289 & 0.147 & 0.32 & 0.084 & -0.272 & -0.345 & 0.107 & $0.446^{* *}$ & 0.273 & $0.45^{* * *}$ \\
\hline Td in June & -0.121 & -0.104 & -0.013 & 0.111 & -0.124 & -0.19 & 0.063 & 0.182 & 0.222 & 0.098 & -0.218 & -0.081 \\
\hline Td in July & $0.385^{*}$ & $0.401^{*}$ & -0.012 & 0.184 & 0.275 & 0.207 & -0.234 & -0.198 & -0.184 & 0.178 & 0.006 & 0.228 \\
\hline Td in August & 0.03 & -0.09 & -0.028 & 0.104 & 0.035 & -0.194 & -0.162 & -0.069 & 0.122 & 0.126 & 0.119 & 0.109 \\
\hline Td in September & -0.213 & -0.217 & 0.013 & -0.013 & -0.178 & -0.218 & 0.11 & 0.107 & -0.034 & -0.085 & -0.115 & -0.102 \\
\hline $\mathrm{Td}$ in October & $0.489 * \%$ & $0.424 *$ & -0.033 & 0.274 & $0.457^{* * *}$ & 0.269 & -0.166 & $-0.408^{*}$ & $-0.378^{*}$ & 0.276 & $0.383^{*}$ & $0.417^{*}$ \\
\hline
\end{tabular}

Fig. 12: Heat map of correlation coefficient between average ground temperature (Td) and tracheid morphological characteristics chronology.

The tracheid length-width ratio is proportional to the tracheid length, so the longer the tracheid length in the corresponding month, the larger the tracheid length-width ratio (Fritts 1976). The increase of tracheid length was dominant to some extent, so the average ground temperature in April and October inhibited the increase of tracheid diameter in a way. October is in the late growing season and excessive ground temperature is not conducive to cell wall thickening (Yasue et al. 2000). However, April and May are in the early growing season, and high ground temperature is conducive to cell wall formation, which is the same as the effect of average temperature on tracheid wall thickness.

\section{CONCLUSIONS}

During the dormancy period of C. funebris trees, tracheid morphological characteristics indicators affected by climatic factors ranged from large to small in order of relative humidity, temperature, precipitation, and sunshine percentage. Relative humidity and temperature were the main climatic factors affecting indicators during dormancy. At the early growth period of trees, 
the indicators affected by climate factors was in the order of relative humidity, temperature, and sunshine percentage, while precipitation had no effect on indicators. During the middle growth period of trees, the indicators affected by climatic factors ranged from large to small in order of relative humidity, temperature, and sunshine percentage, while precipitation had no effect on indicators. In the late growth period of trees, the indicators affected by climatic factors is in turn temperature, relative humidity, and sunshine percentage. Similarly, precipitation has no effect on tracheid morphological characteristics, too.

It was confirmed that temperature and relative humidity play an important role in all growth period of trees, however, the indicators affected by sunshine percentage was less. Besides, precipitation was only related to tracheid length of early wood and latewood, latewood tracheid length-width ratio, and early wood tracheid wall-cavity ratio during dormancy. Temperature and relative humidity were the most important climatic factors affecting the growth of C. funebris trees; however, the tree growth was less affected by sunshine percentage. Precipitation had no significant correlation with most tracheid morphological characteristics.

\section{ACKNOWLEDGMENTS}

The authors are grateful for the support of the Ministry of Education Humanities and Social Sciences Research Project of China (Grant No. 19YJC760009), Key Research and Development Project of Sichuan Science and Technology Plan Projects (Grant No. 2020YFS0357), Project of National Science \& Technology Pillar Program during the 12th Five-year Plan Period (Grant No. 2011BAC09B05), German Government Loans for Sichuan Forestry Sustainable Management Project (Grant No. G1403083), Project of Modern Design and Culture Research Center, Sichuan Key Research Base of Philosophy and Social Sciences (Grant No. MD18Z002) and Opening Foundation for Industrial Design Industry Research Center, Key Research Base of Humanities and Social Sciences, Sichuan Education Department (Grant No. GYSJ18-037).

\section{REFERENCES}

1. Antonova, G.F., Stasova, V.V., 1997: Effects of environmental factors on wood formation in larch (Larix sibirica Ldb.) stems. Trees 11(8): 462-468.

2. Begum, S., Kudo, K., Rahman, M.H., Nakaba, S., Yamagishi, Y., Nabeshima, E., Widyanto D.N., Yuichiro O., Peter K., Hyun-O.J., Funada, R., 2018: Climate change and the regulation of wood formation in trees by temperature. Trees 32(1): 3-15.

3. Chen, M., Li, S., Lyu, J., 2019: Effects of selected joint parameters on tensile strength of steel bolt-nut connections in Cupressus funebris wood. BioResources 14(3): 5188-5211.

4. Chen, M., Li, X., Lyu, J., 2018: Influence of dowel diameter and curing time on strength of double dowel joint. Wood Research 63(4): 591-598.

5. Chen, M., Lyu, J., 2018: Properties of double dowel joints constructed of medium density fiberboard. Maderas. Ciencia y Tecnología 20(3): 369-380.

6. Falster, D.S., Westoby, M., 2005: Alternative height strategies among 45 dicot rain forest species from tropical Queensland, Australia. Journal of Ecology 93(3): 521-535.

7. Fan, C., Li, X.W., Zhuang, J., Li, P., Liu, T., 2014: Fine root distribution characteristics of low-efficiency Cuprssus funebris stands with different transformation modes. Chinese Journal of Ecology 33(7): 1779-1785. 
8. Fritts, H.C., 1976: Tree rings and climate. Academic press Inc., London, U.K., 5-10 Pp.

9. Guo, M.H., Zhao, X. P., 2009: Introduction to wood climatology. Science Press, Beijing, China, Pp 35-87.

10. Guo, M.H., 1999: Relationship between cultivation measures of Pinus koraiensis plantation and wood quality. Doctoral dissertation, Northeast Forestry University, Haerbin, China, Pp 42-83.

11. Hacura, J., Gryc, V., Vavrčík, H., Hozová, J., Urban, J., 2015: The effect of drought on cell wall thickness and radial dimension of tracheids of Picea abies (L.) Karst. Wood Research 60(2): 175-188.

12. Jiang, Q. Wang, D., Guo, T., Yang, C., Lu, F., 2018: Influence of climate factors on radial growth of Pinus tabulaeformis and Quercus acutissima in different site conditions on Culai mountains. Forestry and Ecological Sciences 33(1): 37-43.

13. Jonsson, S., Gunnarson, B., Criado, C., 2002: Drought is the major limiting factor for treering growth of high-altitude Canary Island pines on Tenerife. Geografiska Annaler: Series A, Physical Geography 84(1): 51-71.

14. Kalbarczyk, R., Ziemiańska, M., 2016: The effect of air temperature, precipitation and humidity on ring widths in the black locust (Robinia pseudoacacia L.) growing in urban conditions. Wood Research 61(3): 351-362.

15. Li, J.F., 2000: Research and application of tree ring hydrology. Pp 20-25, Science Press, Beijing, China, Pp 20-25.

16. Lyu, J., Zhao, J., Xie, J., Li, X., Chen, M., 2018: Distribution and composition analysis of essential oils extracted from different parts of Cupressus funebris and Juniperus chinensis. BioResources 13(3): 5778-5792.

17. Masiokas, M., Villalba, R., 2004: Climatic significance of intra-annual bands in the wood of Nothofagus pumilio in southern Patagonia. Trees 18(6): 696-704.

18. Nabais, C., Campelo, F., Vieira, J., Cherubini, P., 2014: Climatic signals of tree-ring width and intra-annual density fluctuations in Pinus pinaster and Pinus pinea along a latitudinal gradient in Portugal. Forestry: An International Journal of Forest Research 87(4): 598-605.

19. Olano, J.M., Eugenio, M., García-Cervigón, A.I., Folch, M., Rozas, V., 2012: Quantitative tracheid anatomy reveals a complex environmental control of wood structure in continental Mediterranean climate. International Journal of Plant Sciences 173(2): 137-149.

20. Samusevich, A., Zeidler, A., Vejpustková, M., 2017: Influence of air pollution and extreme frost on wood cell parameters at mountain spruce stands (Picea abies (L.) Karst.) in the ore mountains. Wood Research 62(1): 79-90.

21. Song, Y.M., Huang, Y.L., 1995: Preliminary study on wood properties variation of loblolly pine. Scientia Silvae Sinicae 31(4): 346-352.

22. Vichrová, G., Vavrčík, H., Gryc, V., Světlík, J., 2013: The analysis of radial growth in stem of Norway spruce by means of different methods and assessment of effect of climatic conditions in relation to the growth. Wood Research 58(2): 217-230.

23. Yasue, K., Funada, R., Kobayashi, O., Ohtani, J., 2000: The effects of tracheid dimensions on variations in maximum density of Picea glehnii and relationships to climatic factors. Trees 14(4): 223-229.

24. Zhao, X.P., Guo, M.H., 2009a: Responses of wood tracheid morphological features of Pinus koraiensis plantation to climatic change. Journal of Northeast Forestry University 37(8): 1-4 .

25. Zhao, X.P., Guo, M.H., 2009b: Relationship between tracheid morphology of Larix gmelinii and climate change. Journal of Northeast Forestry University 37(7): 45-48.

26. Ziemiańska, M., Kalbarczyk, R., 2018: Biometrics of tree-ring widths of (Populus $\mathrm{x}$ canadensis Moench) and their dependence on precipitation and air temperature in southwestern Poland. Wood Research 63(1): 57-74. 
Jianhua Lyu, Weinui Huang, Ming Chen, Xianwei Li*, Shilin Zhong, Siyuan Chen, Jiulong Xie

Sichuan Agricultural University

${ }^{1}$ College of Forestry

Chengdu, Sichuan

CHINA

${ }^{2}$ Wood Industry and Furniture Engineering Key Laboratory of Sichuan Provincial

Department of Education

Chengdu, Sichuan

ChINA

*Corresponding author: 1xw@sicau.edu.cn 
